\title{
PROCR Gene
}

National Cancer Institute

\section{Source}

National Cancer Institute. PROCR Gene. NCI Thesaurus. Code C118582.

This gene plays a role in blood coagulation. 